\title{
Immunosuppressive agents in inflammatory bowel disease: Current status and future
} prospects

Fergus Shanahan mD, Gerald C O'Sullivan Mch, J Kevin COLlins PhD

F SHANAHAN, GC O'SULlivaN, JK COLliNS. Immunosuppressive agents in inflammatory bowel disease: Current status and future prospects. Can J Gastroenterol 1994;8(6):383-387. Inflammatory bowel disease involves an interaction between genetic susceptibility factors and environmental triggers, and the intestinal injury is mediated by the host immunoinflammatory response. Identification of the mechanisms and mediators that contribute to the tissue injury has provided a sound rationale for the therapeutic use of immunosuppressive and immunomodulatory agents. The efficacy of traditional immunosuppressive drugs, such as the purine analogues in both Crohn's disease and ulcerative colitis, is well established. The major limitation of the use of these drugs is the delayed clinical response associated with their use. This has prompted an evaluation of other immunosuppressives, such as cyclosporine and related drugs, that have a more rapid onset of action. Convincing data indicate a distinct role for cyclosporine in certain patients with acute severe ulcerative colitis. However, despite early promising results with cyclosporine in Crohn's disease, recent results have been less encouraging. There is also uncertainty about the exact clinical role of cyclosporine because of concerns regarding long term toxicity. At present, many investigators regard cyclosporine as an interim measure for acutely ill patients. The challenge that remains is the development of novel immunomodulatory strategies that are specific for the mucosal immune system and that are based on recent advances in our understanding of the pathogenesis of mucosal inflammation. (Pour résumé, voir page 384)

Key Words: Crohn's disease, Cyclosporine, Immunosuppression, Purine analogues, Ulcerative colitis

Department of Medicine, Clinical and Molecular Research Group, University College Cork, Cork, Ireland

Correspondence: Dr Fergus Shanahan, Department of Medicine, Cork Regional Hospital, Cork, Ireland. Telephone 353-21-546400 ext 2221, Fax 353-21-343722

This paper was presented at the Trends in Inflammatory Bowel Disease Therapy meeting, April 6 to 9, 1994, held in Victoria, British Columbia. This paper has also been published in Sutherland LR, et al, eds. Inflammatory Bowel Disease: Basic Research, Clinical Implications and Trends in Therapy. Boston, Dordrecht and London: Kluwer Academic Publishers, 1994
TnFammatory BOWEL DISEASE (IBD) has become an exciting area for both the clinician investigator and the basic researcher. Because of improvements in our understanding of the mechanisms and mediators involved in immune-mediated tissue injury, new and exciting forms of immunotherapy are emerging (1-3). The interacting elements that contribute to the pathogenesis of Crohn's disease and ulcerative colitis are summarized in Figure 1. Central to this schema is the concept that tissue damage is mediated by the mucosal immunoinflammatory response $(4,5)$, and therein lies the rationale for the therapeutic use of immunomodulatory agents in these conditions. The various immunomodulatory strategies that have been reported in patients with IBD have been comprehensively reviewed elsewhere (2). What follows is a brief overview of the current status of immunosuppressive therapy in these disorders and a commentary on future prospects.

\section{PURINE ANALOGUES}

The efficacy of the immunosuppressive purine analogues, azathioprine and its active metabolite, 6-mercaptopurine, is generally accepted in both 


\section{Agents immunosuppresseurs dans la maladie inflammatoire de l'intestin}

RÉSUMÉ : La maladie inflammatoire de l'intestin suppose une interaction entre facteurs génétiques prédisposants et déclencheurs environnementaux, et l'atteinte intestinale est modulée par les réponses immuno-inflammatoires de l'hôte. L'identification des mécanismes et des éléments modulateurs impliqués dans les lésions tissulaires justifient le recours à des agents immunosuppresseurs et immunomodulateurs. L'efficacité des agents immunosuppresseurs classiques, comme les antipurines, est bien établie, tant dans la maladie de Crohn que dans la colite ulcéreuse. La principale restriction touchant ces médicaments est la lenteur de la réponse clinique qui leur est associée. Cette lacune a conduit à l'évaluation d'autres immunosuppresseurs, comme la cyclosporine et d'autres médicaments apparentés, qui ont un début d'action plus rapide. Des résultats probants indiquent que la cyclosporine jouerait un rôle distinct chez certains patients atteints de colite ulcéreuse grave et aiguë. Les résultats prometteurs obtenus au début avec la cyclosporine dans la maladie de Crohn n'ont toutefois pas semblé se confirmer récemment. On ignore aussi quel rôle clinique précis peut jouer la cyclosporine, compte tenu sa toxicité à long terme. A l'heure actuelle, de nombreux chercheurs considèrent la cyclosporine comme une solution transitoire lors d'épisodes aigus. Le défi consiste à mettre au point de nouvelles stratégies immunomodulatrices spécifiques au système immunitaire des muqueuses et fondées sur les plus récents progrès accomplis au chapitre de notre compréhension de la pathogenèse de l'inflammation des muqueuses.

Crohn's disease and ulcerative colitis. Although a statistically significant benefit was not obtained in early studies including the National Cooperative Crohn's Disease Study, this can be attributed, in large part, to the relatively short duration of the trials (6). The latency or delayed onset of clinical efficacy of the purine analogues is now recognized. For both Crohn's disease and ulcerative colitis, the role of purine analogues in the treatment of active disease $(7,8)$ and maintenance of remission $(9,10)$ has been convincingly demonstrated in well designed controlled trials.

In practice, these drugs are particularly useful in chronically active Crohn's disease that is uncontrolled by corticosteroids and in patients requiring persistently high doses of steroids for control of disease activity (8). The chief limitation to their use is that they are slow acting, having a mean response time of approximately three months. Because of this, they have no role in the management of acutely ill patients. Also, when these drugs are prescribed it is necessary to continue steroid therapy until sufficient time has elapsed for the immunosuppressant effect to become established.
Although doses up to $2 \mathrm{mg} / \mathrm{kg} /$ day were initially used, most clinicians now use a single daily dose of 50 to $100 \mathrm{mg} /$ day 6-mercaptopurine or $100 \mathrm{mg} /$ day azathioprine. At these low doses, the purine analogues are remarkably well tolerated by patients with IBD, and bone marrow suppression is uncommon $(11,12)$. Indeed, a very low frequency of adverse effects was found in a study of 396 patients with IBD followed for up to 18 years with a mean follow-up of five years (13). Pancreatitis occurs in approximately $3 \%$ of patients. This is probably a hypersensitivity event and precludes further use of either form of purine analogue. Occasionally these drugs produce a debilitating 'flu-like illness that also appears to be a hypersensitivity phenomenon. The most important potential drug interaction may occur if purine analogues are given to patients taking the xanthine oxidase inhibitor, allopurinol. Purine analogues are metabolized by this enzyme and the concomitant use of allopurinol leads to dangerously high drug levels.

While opportunistic infections are uncommon in patients taking low dose 6-mercaptopurine, the most worrisome potential hazard of long term use of purine analogues is the possibility of

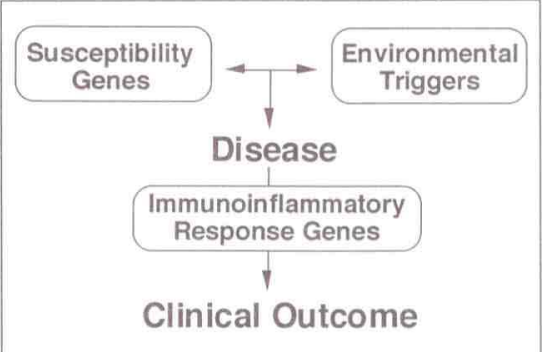

Figure 1) Factors contributing to the pathogenesis of inflammatory bowel disease

opportunistic neoplasia. Whether this is a real or theoretical risk is unclear. It may not be a significant problem with the low doses currently used (13). Many clinicians feel that it is wise to provide patients with a pamphlet that attempts to place in perspective the theoretical risks associated with these drugs in addition to their well established benefits.

\section{METHOTREXATE}

The folic acid antagonist methotrexate has been found to have clinical efficacy in a variety of immunologically mediated disorders. The molecular mechanism by which methotrexate suppresses inflammation has recently been clarified (14). Its action involves a series of biochemical steps that promote the local release of adenosine. Adenosine has a variety of receptormediated immunomodulatory properties and inhibits the generation of toxic oxygen metabolites from neutrophils (14).

In an open study of patients with IBD, methotrexate was found to have a marked beneficial effect in some patients, particularly those with Crohn's colitis (15). Some of these patients were refractory to other treatments including steroids and 6-mercaptopurine, and responded to high dose methotrexate $25 \mathrm{mg}$ intramuscularly over a 12 -week period. Lower doses of methotrexate may also have a steroid-sparing effect (16). However, the clinical usefulness of methotrexate is limited by adverse effects which include leukopenia, gastrointestinal toxicity, hypersensitivity pneumonitis and hepatic dysfunction. For this reason, methotrexate is probably best reserved for pa- 
tients who are refractory to or are intolerant of purine analogues.

\section{CYCLOSPORINE}

The delayed induction of clinical response associated with purine analogues and methotrexate prompted an investigation of other immunomodulatory agents that might have a more rapid onset of clinical efficacy in acutely ill patents with IBD $(17,18)$. Cyclosporine has a rapid onset of action, and is thought to suppress the induction and amplification of the immune response by inhibiting cytokine gene activation, particularly interleukin-2 $(2,18,19)$. More recently, evidence for an additional mode of action has emerged that may have particular relevance in IBD. The cyclosporine binding protein cyclophilin, which had been considered to be an intracellular protein, has recently been shown to be a secretory product of activated macrophages. Furthermore, it has cytokinelike, preinflammatory activity with chemotactic effects on neutrophils and eosinophils (19-21). It has been proposed that this, rather than inhibition of cytokine production, may be the primary immunomodulatory mechanism of action of cyclosporine (22).

One placebo controlled study of oral cyclosporine in patients with Crohn's disease who were intolerant of or resistant to corticosteroids has been published (24). Of 37 patients, 22 (59\%) improved on cyclosporine (5 to 7.5 $\mathrm{mg} / \mathrm{kg} /$ day for three months) compared with 11 of $34(32 \%)$ receiving placebo. The improvement was evident after only two weeks. However, the preliminary results of a second placebo-controlled trial that have been reported in abstract form suggest a cautious approach to the use of cyclosporine in Crohn's disease (24). This large ongoing Canadian study found that cyclosporine $4.8 \mathrm{mg} / \mathrm{kg}$ is ineffective as therapy for Crohn's disease, and may even have an adverse effect on disease activity in patients in remission.

Several factors limit the long term use of cyclosporine. These include its wide range of serious toxic side effects, the need for close monitoring of blood levels, the variable bioavailability when given by the oral route and the frequency of drug interactions (2). Many clinicians regard the role of cyclosporine in acute Crohn's disease as a short term measure, at best. Whether it has an interim role before more slowacting drugs such as 6-mercaptopurine take full effect needs to be assessed.

In contrast to Crohn's disease, cyclosporine appears to have a rapid and dramatic beneficial effect in patients with acute severe ulcerative colitis $(25,26)$. In a preliminary open study of patients with severe ulcerative colitis who had failed to respond to intravenous steroids over 10 days, treatment was supplemented with intravenous cyclosporine $4 \mathrm{mg} / \mathrm{kg} / \mathrm{day}$. Remission was achieved in about $80 \%$ of the patients and surgery was avoided (25). Similar results were found in a subsequent double-blind trial. In fact, the trial was halted after $82 \%$ of the patients on cyclosporine responded whereas none of those on placebo improved (26). For patients with severe colitis who have not responded to traditional treatment with steroids and who are either not suited or not psychologically ready for colectomy, cyclosporine offers a welcome new option.

Topical enema preparations of cyclosporine have also been used in patients with resistant proctitis $(27,28)$. However, although several open studies have been encouraging, a recent controlled trial of cyclosporine enemas in patients with mild to moderate ulcerative colitis failed to show a significant therapeutic benefit (29).

\section{OTHER IMMUNOMODULATORY STRATEGIES}

The introduction of newer immunosuppressive drugs, such as the macrolides, rapamycin and FK506, may eclipse cyclosporine in clinical use during the next decade $(2,30)$. Studies of FK506 in IBD are already underway (31). Its mode of action is similar to that of cyclosporine but it is approximately 100-fold more potent. Its toxicity is also likely to be similar, although early data have suggested that it occurs with a lower frequency than with cyclosporine. Its efficacy in intestinal transplantation has been particularly impressive but whether this implies a greater specificity for the intestinal mucosal immune system than occurs with cyclosporine is not clear (32).

Intravenous immunoglobulin therapy appears to have a beneficial effect in a variety of immunologically mediated disorders although its mechanism of action is uncertain. In a recent open study of patients with IBD, some patients appeared to benefit (33). This is a cumbersome and expensive form of therapy and is unlikely to eclipse other therapeutic strategies. The same limitations apply to the use of $\mathrm{T}$ cell apheresis even though its efficacy in Crohn's disease appears impressive from the results of a recent open study (34). A similar outcome can now be achieved with monoclonal antibodies to specific $T$ cell subsets (35).

Cytokine modulation and antagonism is perhaps one of the more exciting recent approaches to therapeutic immunomodulation. Cytokines are the regulatory and effector intercellular messenger molecules of the immune response. They are, thus, ideal targets for selective immunotherapy (36). Encouraging preliminary results of cytokine antagonism directed against interleukin-1 in animal models of intestinal inflammation $(37,38)$ and against tumour necrosis factor in humans with IBD (39), have already been reported.

\section{PROSPECTS AND PREDICTIONS}

It is likely that the pharmaceutical industry will continue to introduce modifications that improve either the biological activity or the delivery systems for most of the traditional immunosuppressive drugs. For example, newer purine analogues are already in use for certain leukemias (40) Whether these agents will have a role in the management of chronic inflammatory disease is unknown. There is also the potential and rationale for developing another generation of cyclosporine-like drugs. As discussed earlier, cyclosporine and related drugs may act primarily by inhibiting the chemotactic activity of secreted cyclophilin. It has been proposed that this mecha- 
nism, rather than inhibition of interleukin-synthesis, is responsible for the therapeutic effect in both organ graft survival and chronic inflammatory disorders (23). If this is true, it would be desirable to develop novel agents, including cyclosporine derivatives, that are potent inhibitors of chemotaxis with less effect on cytokine synthesis by $\mathrm{T}$ cells. The potential for selectively removing subsets of $T$ cells by monoclonal antibodies has been facilitated by the ability to engineer 'humanized' antibodies (41) and by the identification of several new receptor/ligand interactions on the $T$ cell surface that influence activation and physiological cell death $(35,42)$. For example, rather than targeting an entire CD4 subpopu-

\section{REFERENCES}

1. Bernstein CN, Shanahan F. Immunosuppressive and immunomodulatory therapy for inflammatory bowel disease. Can J Gastroenterology 1993;7:115-20.

2. Bernstein CN, Shanahan F. Immunomodulatory therapy in inflammatory bowel disease. In: Targan S, Shanahan F, eds. Inflammatory Bowel Disease: From Bench to Bedside. Baltimore: Williams \& Wilkins, 1994:503-23.

3. Shanahan F, Targan S. Medical treatment of inflammatory bowel disease. Annu Rev Med 1992;43:125-33.

4. Shanahan F, Targan S. Mechanisms of tissue injury in inflammatory bowel disease. In: Targan S, Shanahan F, eds. Inflammatory Bowel Disease: From Bench to Bedside. Baltimore: Williams \& Wilkins, 1994:78-88.

5. Shanahan F. Pathogenesis of ulcerative colitis. Lancet 1993;342:407-11.

6. Summers RW, Switz DM, Sessions JT Jr, et al. National Cooperative Crohn's Disease Study: results of drug treatment. Gastroenterology 1979;77:847-69.

7. Present DH, Korelitz BI, Wisch N, Glass JL, Sacher DB, Pasternack BS. Treatment of Crohn's disease with 6-mercaptopurine. A long term randomized double blind study. N Engl J Med 1980;302:981-7.

8. Ewe K, Press AG, Singe CC, et al. Azathioprine combined with prednisolone or monotherapy with prednisolone in active Crohn's disease. Gastroenterology 1993;105:367-72.

9. O'Donoghue DP, Dawson AM, Powell-Tuck J, Brown RL, Lennard-Jones JE. Double-blind lation, it may be more appropriate to use monoclonal antibodies directed to molecules on the $\mathrm{T}$ cell surface that are responsible for physiological cell death and termination of autoreactive lymphocytes during development. Thus, an antibody directed toward the Apo-I/ Fas antigen may selectively eliminate a subset of activated $T$ cells by apoptosis $(43,44)$. Thus, it may be possible to exploit endogenous mechanisms for lymphocyte cell death for beneficial effect in chronic inflammatory disorders with minimal collateral damage or toxicity.

From a clinical perspective, immunosuppressive strategies are likely to be used widely. The traditional use of drugs on an empiric basis has been re-

withdrawal trial of azathioprine as maintenance treatment of Crohn's disease. Lancet 1978;ii:955-7.

10. Hawthorne AB, Logan RFA, Hawkey CJ, et al. Randomized controlled trial of azathioprine withdrawal in ulcerative colitis. Br Med J 1990;305:20-2.

11. Bernstein CN, Artinian L, Anton PA, Shanahan F. Low dose 6-mercaptopurine in inflammatory bowel disease is associated with minimal hematologic toxicity. Dig Dis Sci. (In press)

12. Connell WR, Kamm MA, Ritchie JK, Lennard-Jones JE. Bone marrow toxicity caused by azathioprine in inflammatory bowel disease: 27 years of experience. Gut 1993;34:1081-5.

13. Present DH, Meltzer SJ, Krumholz MP, Wolke A, Korelitz BI. 6-Mercaptopurine in the management of inflammatory bowel disease: short- and long-term toxicity. Ann Intern Med 1989;111:641-9.

14. Cronstein BN, Naime D, Ostad E. The antiinflammatory mechanism of methotrexate. Increased adenosine release at inflamed sites diminishes leukocyte accumulation in an in vivo model of inflammation. J Clin Invest 1993;92:2675-82.

15. Kozarek RA, Patterson DJ, Gelfand MD, Botoman VA, Ball TJ, Wilske KR. Methotrexate induces clinical and histologic remission in patients with refractory inflammatory bowel disease. Ann Intern Med 1989;110:353-6.

16. Baron TH, Truss CD, Elson CO. Low-dose oral methotrexate in refractory inflammatory bowel disease. Dig Dis Sci 1993;38:1851-6.

17. Brynskov J. Cyclosporin for inflammatory bowel disease: placed by approaches that have a sound rationale and are based on improved understanding of the pathogenesis of IBD. Because of the remarkable reserve of mediators within the inflammatory cascade, it is likely that combination therapy should be used rather than a stepwise approach. Unlike rheumatologists, gastroenterologists have been slow to adopt this concept and may have much to benefit by earlier use of disease-modifying drugs such as immunosuppressives for chronic inflammatory disease. Finally, future immunomodulatory strategies should target the mucosal immune system rather than the systemic immune response and should focus on maintenance of disease remission rather than treatment of relapse.

mechanisms and possible actions.

Scand J Gastroenterol 1993;28:849-57.

18. Sandbom WJ, Trcmaine WJ.

Cyclosporine treatment of

inflammatory bowel disease. Mayo

Clin Proc 1992;67:981-90.

19. Sigal NH, Dumont FJ. Cyclosporin A, FK-506, and rapamycin:

pharmacologic probes of lymphocyte signal transduction. Annu Rev Immunol 1992;10:519-60.

20. Schrieber SL, Crabtree GR. The mechanism of action of cyclosporin A and FK506. Immunol Today 1992;13:136-42.

21. Sherry B, Yarlett N, Strupp A, Cerami A. Identification of cyclophilin as a proinflammatory secretory product of lipopolysaccharide-activated macrophages. Proc Natl Acad Sci USA 1992;89:3511-5.

22. Xu Q, Leiva MC, Fischkoff SA, Handschumacher RE, Lyttle CR. Leukocyte chemotactic activity of cyclophilin. J Biol Chem 1992;267:11968-71

23. Erlanger BF. Why cyclosporin is an effective drug. Immunol Today 1993; 14:369. (Lett)

24. Brynskov J, Freund L, Rasmussen SN, et al. A placebo-controlled double-blind randomized trial of cyclosporine therapy in active chronic Crohn's disease. N Engl J Med 1989;321:845-50.

25. Archambault A, Feagan B, Fedorak R, et al. The Canadian Crohn's relapse prevention trial (CCRPT). Gastroenterology 1992;102:A591.

26. Lichtiger S, Present DH. Preliminary report: Cyclosporin in the treatment of severe active ulcerative colitis. Lancet 1990;336:16-9.

27. Lichtiger S, Present DH, Kornbluth A, 
Hanauer SB. Cyclosporine A in the treatment of severe refractory ulcerative colitis: a double blinded placebo controlled trial.

Gastroenterology 1993;104:A732

28. Brynskov J, Freund L, Thomsen OO, et al. Treatment of refractory ulcerative colitis with cyclosporin enemas. Lancet 1989;i:721-2.

29. Sandbom WJ, Tremaine WJ, Schroeder KW, et al. A randomized, double-blind, placebo-controlled trial of cyclosporine enemas for mildly to moderately active left-sided ulcerative colitis. Gastroenterology 1993;104:A775. (Abst)

30. Macleod AM, Thomson AW. FK506: an immunosuppressant for the 1990's? Lancet 1991;337:25-37.

31. Reynolds JC, Trellis DR, Abu-Elmgd $\mathrm{K}$, Fung J. The rationale for FK506 in inflammatory bowel disease. Can J Gastroenterol 1993;7:208-10.

32. Todo S, Tzakis A, Teves J, et al. Intestinal transplantation in humans under FK506. Transplant Proc 1993;25:1198-9.

33. Levine DS, Fischer SH, Haggitt RC, Christie DL, Ochs HD. Intravenous immunoglobulin therapy for active, extensive, and medically refractory idiopathic ulcerative colitis or Crohn's colitis. Am J Gastroenterol 1992;87:91-100.

34. Bicks RO, Groshart KD. The current status of T-lymphocyte apheresis (TLA) treatment of Crohn's disease. J Clin Gastroenterol 1989;11:136-8.

35. Waldmann TA. Immune receptors: targets for therapy of leukemia/ lymphoma, autoimmune diseases and for the prevention of allograft rejection. Annu Rev Immunol 1992;10:675-704.

36. Waldmann TA, Grant A, Tendler C, et al. Lymphokine receptor-directed therapy: a model of immune intervention. J Clin Immunol 1990;10:19-28S.

37. Cominelli F, Nast CC, Clark BD, et al. Interleukin-1 gene expression, synthesis and effect of special IL-1 receptor blockade in rabbit immune complex colitis. J Clin Invest 1990;86:972-80.

38. Sartor RB, Holt LC, Bender DE, Murphy ME, McCall RD, Thompson
RC. Prevention and treatment of experimental enterocolitis with a recombinant interleukin-1 receptor antagonist. Gastroenterology 1991;100:A613.

39. Derkx B, Taminiau J, Radema S, et al. Tumor necrosis factor antibody treatment in Crohn's disease. Lancet 1993;342:173-4.

40. Saven A, Piro L. Newer purine analogues for the treatment of hairy-cell leukemia. N Engl J Med 1994;330:691-7.

41. Winter G, Harris WJ. Humanized antibodies. Immunol Today 1993;14:243-6.

42. Adorini L, Guery J-C, RodriguizTargduchy G, Trembleau S. Selective immunosuppression. Immunol Today 1993;14:285-9.

43. Trauth BC, Klas C, Peters AMJ, et al. Monoclonal antibody-mediated tumor regression by induction of apoptosis. Science 1989;245:301-5.

44. Suda T, Takahashi T, Goldstein P, Nagata S. Molecular cloning and expression of the Fas ligand, a novel member of the tumor necrosis factor family. Cell 1993;75:1169-78. 


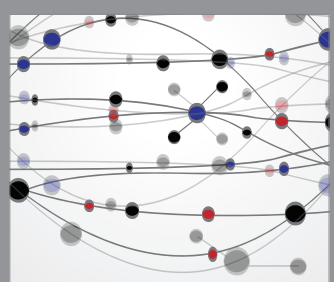

The Scientific World Journal
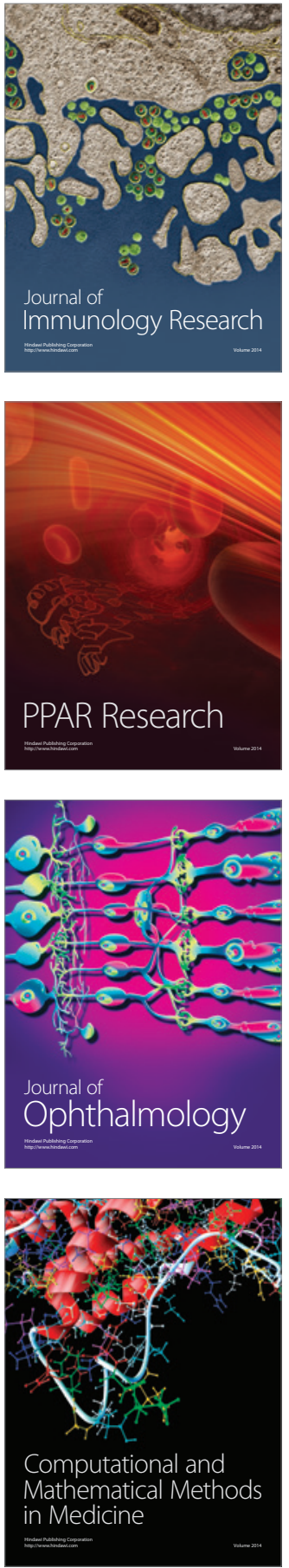

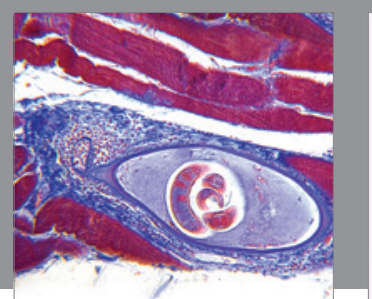

Gastroenterology Research and Practice

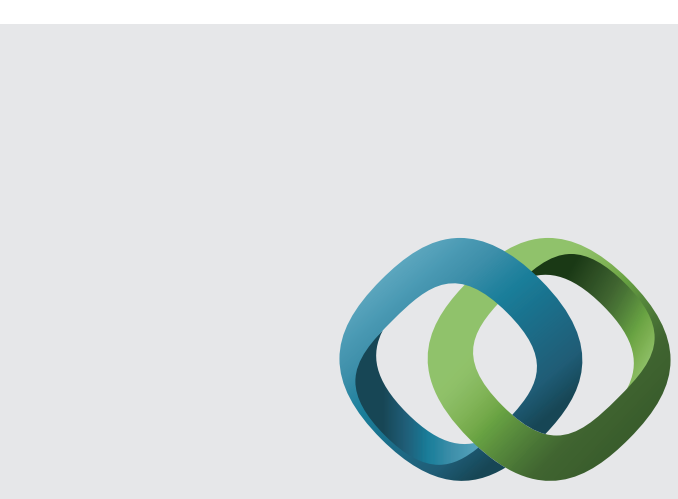

\section{Hindawi}

Submit your manuscripts at

http://www.hindawi.com
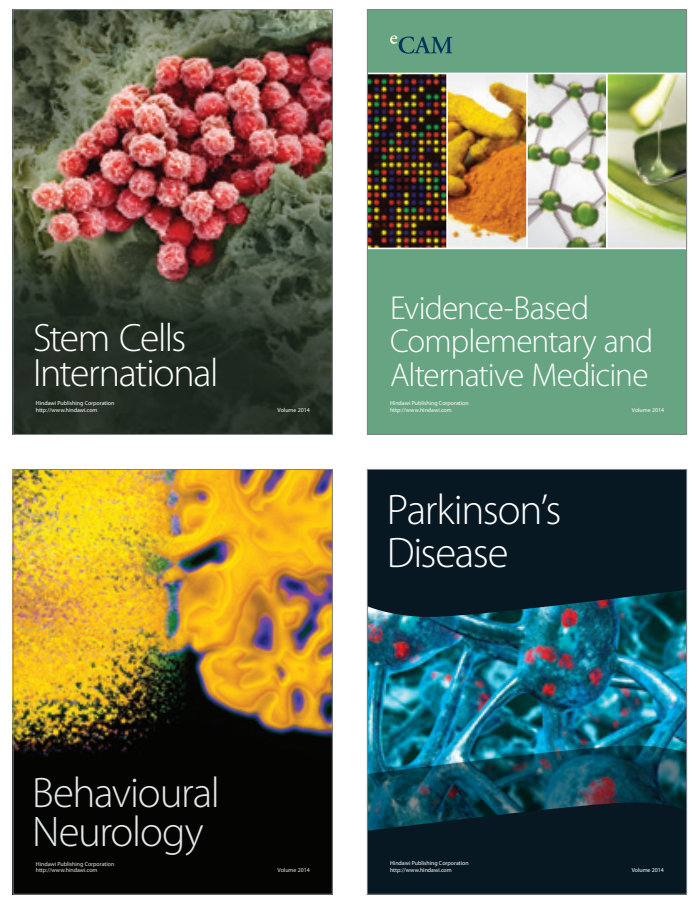
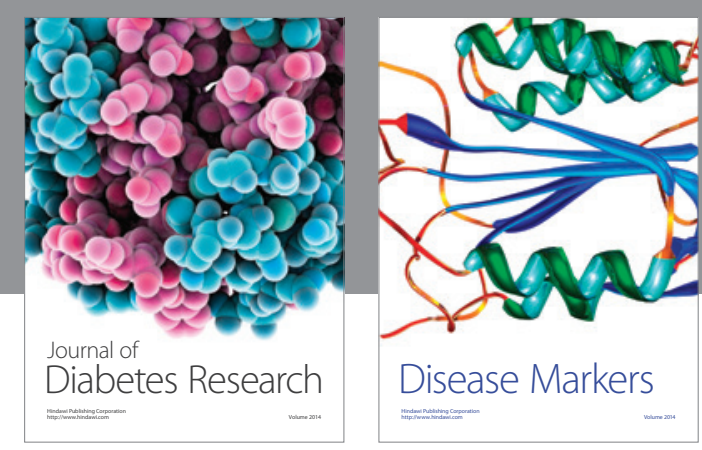

Disease Markers
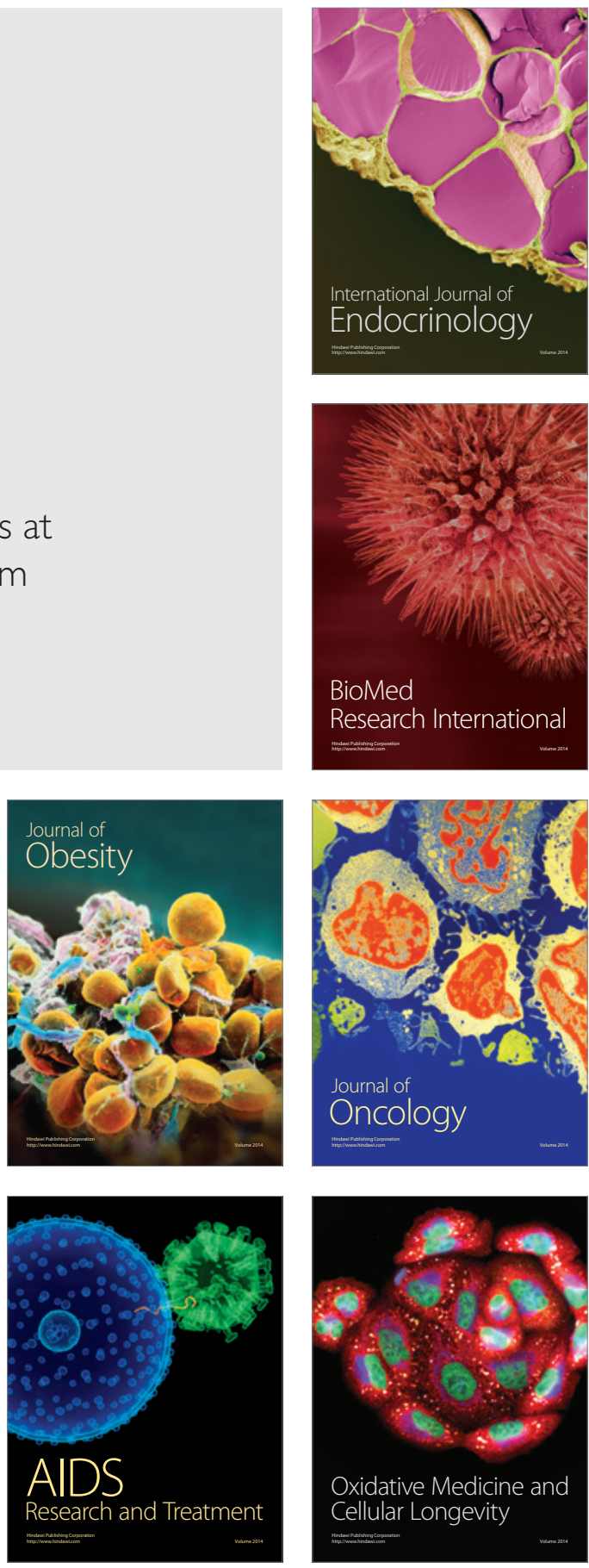